\title{
ANALISIS IMPLEMENTASI PENANGANAN PEMBIAYAAN MUDHARABAH BERMASALAH DI KSPPS BMT BINA UMMAT SEJAHTERA CABANG MIJEN KUDUS
}

\author{
Fuad Riyadi \& Sri Puji Lestari \\ Dosen STAIN Kudus \\ Email: abuhabib12344gmail.com Envia36@gmail.com
}

\begin{abstract}
Mudharabah is a special kind of partnership between two parties, where one partner providers the capital executed (shahibul mal) and the other supplying the labor and skill as agent or manager (mudharib), for investing in a predetermined activity, which grants each party a share of the earnings as determined at the time of the investment. On this Implementation while the risk in financing mudharabah, especially on this the financing application, high relatively, among other side streaming, negligence and misconduct willful, concealment of profits by customers when customers are not honest. The amount of financing risk is shown in the ratio of non-performing finance. The high of non-performing finance indicates the large number of borrowers who can't repay their finance in accordance with the initial agreement that has been agreed between the bank and the customer, so financing becomes problematic. Funding problems can be caused by the bank itself, the customers or external parties. KSPPS BMT Bina Ummat Sejahtera Mijen Kudus has been anticipating the event of a dispute banking, especially in the provision of financing problems. On this theory of completion financing problems, be done with several measures including the rescue action by intensive bill, rescheduling, re-requirements and realignment. Rescue actions made by bank on this condition that the customer is still considered to have good faith to settle the payment.
\end{abstract}

Keywords: implementasi, penanganan, mudharabah bermasalah.

\section{A. Pendahuluan}

Dinamika perkembangan lembaga keuangan syariah bank atau non bank di Indonesia adalah satu sisi yang menarik untuk 
dikaji. Ada optimisme yang besar bagi pendiri lembaga keuangan syariah karena mayoritas penduduk Indonesia beragama Islam, hal itu akan menjadi peluang yang besar untuk eksisnya keberadaan lembaga keuangan dengan prinsip syariah.

Dalam BAB II Pasal 3 Undang-Undang Nomor 10 Tahun 1998 perubahan atas Undang-Undang Nomor 7 Tahun 1992 tentang perbankan dijelaskan bahwa fungsi perbankan adalah sebagai penghimpun dan penyalur dana masyarakat, tujuan perbankan lebih jauh dalam pasal 4 undang-undang tersebut adalah untuk menunjang pelaksanaan pembangunan nasional dalam melaksanakan peningkatan pemerataan, pertumbuhan ekonomi dan stabilitas nasional kearah peningkatan kesejahteraan rakyat banyak.(Makhalul Ilmi, 2002:91).

Baitul Maal Wat Tanwil (BMT) merupakan lembaga keuangan mikro syariah yang kegiatannya menghimpun dana dari anggota atau calon anggota untuk disimpan dan disalurkan dalam bentuk pembiayaan syariah kepada sektor ekonomi yang halal dan menguntungkan khususnya usaha-usaha kecil, kecil kebawah, dan mikro.(Didiek Ahmad Supadie, 2013:24)

Menurut PP No. 9 tahun 1998, tentang pelaksanaan simpan pinjam oleh koperasi, pengertian pinjaman adalah:

"Penyediaan uang atau tagihan yang dapat dipersamakan dengan itu, berdasarkan tujuan atau kesepakatan pinjam meminjam antara koperasi dengan pihak lain yang mewajibkan pihak peminjam untuk melunasi hutangnya setelah jangka waktu tertentu dengan disertai pembayaran sejumlah imbalan".(Kasmir, 2002:73).

Pembiayaan berdasarkan prinsip syariah oleh bank mengandung risiko kegagalan atau kemacetan pelunasannya, sehingga dapat berpengaruh terhadap kesehatan bank. Oleh karena itu, untuk memelihara kesehatan dan meningkatkan daya tahannya, bank diwajibkan menyebar resiko dengan mengatur penyaluran kredit, pembiayaan, atau pemberian jaminan dan fasilitas lain sedemikian rupa sehingga tidak terpusat pada debitur atau sekelompok nasabah tertentu. (Muhammad Ridwan, 2005: 358-359). 
Koperasi Simpan Pinjam dan Pembiayaan Syari'ah Baitul Maal WatTamwil Bina Ummat Sejahtera (KSPPS BMT BUS) merupakan lembaga jasa keuangan mikro syariah yang berada di bawah naungan koperasi yang melakukan kegiatan jasa simpanpinjam.BMT ini didirikan dengan tujuan untuk membantu dalam peningkatan taraf hidup anggota, khususnya dalam bidang ekonomi.Dan telah melakukan berbagai pembinaan usaha kecil kepada masyarakat, melaui sistem Ekonomi Syariah dengan penerapan bagi hasil dalam setiap transaksi (akad). KSPPS BMT Bina Ummat Sejahtera berkantor pusat di Jl. Untung Suropati No. 16 Lasem, Rembang, Jawa Tengah yang mempunyai 104 Kantor cabang di beberapa propinsi yaitu Jawa Tengah, Jawa Timur, D.I Yogyakarta, Jawa Barat, DKI Jakarta, dan Kalimantan Barat. Salah satukantor cabang yang berada di Jawa Tengah yaitu KSPPS BMT Bina Ummat Sejahtera cabang Mijen Kudus yang merupakan cabang utama Kudus. BMT BUS cabang Mijen Kudus berperan sebagai lembaga keuangan syariah yang menyalurkan dan menghimpun dana, termasuk juga dalam menyalurkan beberapa pembiayaan. Adapun letak geografis BMT BUS cabang Mijen Kudus berada di Jl. Raya Kudus Jepara KM 5 Mijen, Kudus. BMT BUS cabang Mijen memiliki 7 karyawan, 5 pada BMT BUS dan 2 pada Area BMT BUS cabang Mijen Kudus mempunyai 318 nasabah/anggota dengan akad Mudharabah.

Pembiayaan Mudharabah adalah akad pembiayaan antara dua pihak, dimana BMT sebagai shahibul maal (penyedia modal) dan anggota sebagai mudhorib (pengelola usaha), atas kerjasama ini berlaku sistem bagi hasil dengan ketentuan nisbah sesuai kesepakatan kedua belah pihak. Dari akad pembiayaan tersebut tidak jarang pembiayaan yang disalurkan mengalami masalah. Karena nasabah/anggota tidak mampu menyelesaikan pembiayaan sebagaimana mestinya atau melampaui batas waktu yang ditentukan sesuai perjanjian pembiayaan yang telah disepakati bersama sehingga menyebabkan pembiayaan bermasalah. Sesuai laporan rekap nominatif pembiayaan pada KSPPS BMT Bina Ummat Sejahtera Cabang Mijen, adapun persentase rinciannya sebagai berikut: 
Tabel 1.1

\begin{tabular}{cccc}
\hline Kode & Keterangan & Jml Rek & Persen \\
\hline L & Lancar & 55 & $11,85 \%$ \\
KL & Kurang Lancar & 17 & $5,28 \%$ \\
D & Diragukan & 25 & $20,74 \%$ \\
M & Macet & 234 & $62,12 \%$ \\
& Jumlah & & $100 \%$ \\
\hline
\end{tabular}

Berdasarkan data diatas dapat diketahui bahwa jumlah pembiayaan dengan kategori macet merupakan persentase tertinggi yaitu $62,12 \%$.

\section{B. Pembahasan}

\section{Definisi Mudharabah}

Mudharabah, berasal dari kata dharb, artinya memukul atau berjalan.Sayyid Sabiq (mendefinisikan, Mudharabah berasal dari kata الضربفيالارض (adharbu fil ardhi), yang artinya السفرللتجارة (assafaru littajaarati) melakukan perjalanan untuk berdagang.(Sayyid Sabiq,tt.:147).Pengertian memukul atau berjalan ini lebih tepatnya adalah proses seseorang memukulkan kakinya dalam menjalankan usaha. Secara teknis mudharabah adalah akad kerja sama usaha antara dua pihak di mana pihak lainnya menjadi pengelola.

Mudharabah adalah akad kerja sama antara pemilik dana (shahibul maal), yang menyediakan seluruh kebutuhan modal, dan pihak pengelola usaha (mudharib) untuk melakukan suatu kegiatan usaha bersama. Keuntungan yang diperoleh dibagi menurut perbandingan (nisbah) yang disepakati.

Keuntungan usaha secara mudharabah dibagi menurut kesepakatan yang dituangkan dalam kontrak, sedangkan kerugian ditanggung oleh pemilik modal selama kerugian itu bukan akibat kelalaian pengelola, maka pengelola harus bertanggung jawab atas kerugian tersebut.Atas kerjasama ini berlaku sistem bagi hasil dengan ketentuan nisbah sesuai kesepakatan kedua belah pihak. Secara lebih spesifik, pengertian mudharabah dapat diperinci sebagai berikut:

1. Mudharabah adalah akad kerja sama antara pemilik dana (shahibul maal), yang menyediakan seluruh kebutuhan modal, dan pihak pengelola usaha (mudharib) untuk melakukan 
Analisis Implementasi Penanganan Pembiayaan Mudharabah Bermasalah...

suatu kegiatan usaha bersama. Keuntungan yang diperoleh dibagi menurut perbandingan (nisbah) yang disepakati.

2. Dalamhal terjadi kerugian, maka ditanggung oleh pemilik modal selama bukan diakibatkan kelalaian pengelola usaha. Sedangkan, kerugian yang timbul karena kelalaian pengelola akan menjadi tanggung jawab pengelola usaha itu sendiri.

3. Pemilik modal tidak turut campur dalam pengelola usaha, tetapi mempunyai hak untuk melakukan pengawasan.

\section{Dasar Hukum Mudharabah}

Dasar hukum disyariatkannya al-mudharabah adalah $\mathrm{Al}$ Qur'an, as Sunnah dan Ijma'. AL Qur'an dalam Firman Allah SWT dalam surat al-Jumu'ah: 10.

"Apabila telah ditunaikan sholat, maka bertebarkanlah kamu di muka bumi dan carilah karunia Allah dan ingatlah Allah banyakbanyak supaya kamu beruntung.

Firman Allah QS. Al-Baqarah: 283.

“...Maka, jika sebagian kamu mempercayai sebagian yang lain, hendalkah yang dipercayai itu mennuaikan amanatnya".

Dalam hadits, diriwayatkan dari Ibnu Abbas ra, berkata ia:

Abbas bin Abdul Muthalib ketika menyerahkan hartanya sebagai mudharabah, ia mensyaratkan kepada mudharibnya agar tidak mengarungi lautan dan tidak menuruni lembah, serta tidak membeli hewan ternak. Jika persyaratannya dilanggar, ia (mudharib) harus menanggung risikonya. Maka sampai persyaratan itu kepada Rasululah saw, dan beliau memperbolehkannya. (ThabraniHR. Thabrani, Al Mu'jam al Ausath, Awalu Kitab, no. Hadits 760. Dar al Haramain, Kairo, 1415 H juz 1, Hlm. 231. Maktabah Syamilah)

Ijma. Diriwayatkan, sejumlah sahabat menyerahkan (kepada orang, mudharib) harta anak yatim sebagai mudharabah dan tak ada seorang pun mengingkari mereka. Karenanya, hal itu dipandang sebagai ijma'.(Wahbah Zuhaily, 5/3925).

Unsur (rukun) perjanjian mudharabah tersebut adalah:

1. Ijab dan qabul

2. Adanya dua pihak (pihak penyedia dana dan pengusaha)

3. Adanya modal

4. Adanya usaha ('amal)

5. Adanya keuntungan. (Veithzal Rivai, 2008: 123-130). 


\section{Pembiayaan Mudharabah}

Istilah pembiayaan pada intinya berarti I Believe, I Trust,'saya percaya' atau 'saya menaruh kepercayaan'.Perkataan pembiayaan yang artinya kepercayaan (trust), berarti lembaga pembiayaan selaku shohibul maal menaruh kepercayaan kepada seseorang untuk melaksanakan amanah yang diberikan.Dana tersebut harus digunakan dengan benar, adil, dan harus disertai dengan ikatan dan syarat-syarat yang jelas, dan ssling menguntungkan bagi kedua belah pihak.(Veithzal Rivai, 2008:3).

Sebagaimana firman Allah SWT dalam surat An-Nisa (4): 29 dan surat Al-Ma'idah (5): 1.

"Wahai orang-orang yang beriman! Janganlah kamu saling memakan harta sesamamu dengan jalan yang batil(tidak benar), kecuali dalam perdagangan yang berlaku atas dasar suka sama-suka di antara kamu.Dan janganlah kamu membunuh dirimu. Sungguh, Allah Maha Penyayang kepadamu".(Qs An-Nisa: 29)

"Hai orang-orang yang beriman, penuhilah aqad-aqad itu". (AlMaidah:1)

Menurut Undang-Undang Perbankan nomor 10 tahun 1998, kredit adalah penyediaan uang atau tagihan yang dapat dipersamakan dengan itu, berdasarkan persetujuan atau kesepakatan pinjam meminjam antara bank dengan pihak lain yang mewajibkan pihak peminjam melunasi utangnya setelah jangka waktu tertentu dengan pemberian bunga. (Kasmir, 2002:73).

Sedangkan pembiayaan menurut prinsip syariah adalah penyediaan uang atau tagihan yang dipersamakan dengan itu berdasarkan persetujuan atau kesepakatan antara bank dengan pihak lain yang mewajibkan pihak yang dibiayai dengan imbalan atau bagi hasil.(Kasmir, 2002:73).

Pembiayaan merupakan aktivitas bank syariah dalam menyalurkan dana kepada pihak lain selain bank berdasarkan prinsip syariah. Penyaluran dana dalam bentuk pembiayaan didasarkan pada kepercayaan yang diberikan oleh pemilik dana kepada pengguna dana.(Ismail, 2011:105-106).

Menurut sifat penggunaanya, pembiayaan dapat dibagi menjadi dua hal berikut: 
Analisis Implementasi Penanganan Pembiayaan Mudharabah Bermasalah...

Pembiayaan produktif, yaitu pembiayaan yang ditujukan untuk memenuhi kebutuhan produksi dalam arti luas, yaitu untuk peningkatan usaha, baik usaha produksi, perdagangan, maupun investasi.

Menurut keperluannya, pembiayaan produktif dapat dibagi menjadi dua hal berikut:

1. Pembiayaan modal kerja, yaitu pembiayaan untuk memenuhi kebutuhan:

a. peningkatan produksi, baik secara kuantitatif, yaitu jumlah hasil produksi, maupun secara kualitatif, yaitu peningkatan kualitas atau mutu hasil produksi.

b. untuk keperluan perdagangan atau peningkatan utility of place dari suatu barang.

2. Pembiayaan investasi, yaitu untuk memenuhi kebutuhan barang-barang modal (capital goods) serta fasilitas-fasilitas yang erat kaitannya dengan itu.

3. Pembiayaan konsumtif, yaitu pembiyaan yang digunakan untuk memenuhi kebutuhan konsumsi, yang akan habis digunakan untuk memenuhi kebutuhan. (Muhammad Syafi'i Antonio, 2001:160-161)

\section{Pembiayaan Muharabah Bermasalah dan Bentuk-bentuknya}

Pembiayaan bermasalah adalah suatu keadaan dimana nasabah sudah tidak sanggup membayar sebagian atau seluruh kewajibannya kepada bank seperti yang telah diperjanjikan dalam perjanjian kredit. (Suhardjono, 2003:252)

Ada beberapa pengertian mengenai pembiayaan bermasalah yaitu:

1. Kredit yang di dalam pelaksanaannya belum mencapai/ memenuhi target yang diinginkan oleh pihak bank,

2. Kredit yang memiliki kemungkinan timbulnya risiko di kemudian hari bagi bank dalam arti luas,

3. Mengalami kesulitan di dalam penyelesaian kewajibankewajibannya, baik dalam bentuk pembayaran kembali pokoknya dan/atau pembayaran bunga, denda 
keterlambatan serta ongkos-ongkos bank yang menjadi beban debitur yang bersangkutan,

4. Kredit di mana pembayaran kembalinya dalam bahaya, terutama apabila sumber-sumber pembayaran kembali yang diharapkan diperkirakan tidak cukup untuk membayar kembali kredit, sehingga belum mencapai/memenuhi target yang diinginkan oleh bank,

5. Kredit di mana terjadi cedera janji dalam pembayaran kembali sesuai perjanjian, sehingga terdapat tunggakan, atau ada potensi kerugian di perusahaan debitur sehingga memiliki kemungkinan timbulnya risiko di kemudian hari bagi bank dalam arti luas,

6. Mengalami kesulitan di dalam penyelesaian kewajiabankewajibannya terhadap bank, baik dalam bentuk pembayaran kembali pokoknya, pembayaran bunga, pembayaran ongkos-ongkos bank yang menjadi beban nasabah/debitur yang bersangkutan,

7. Kredit golongan perhatian khusus, kurang lancar, diragukan, dan macet serta golongan lancar yang berpotensi menunggak. (Veithzal Rivai, 2013: 398)

\section{Penanganan Pembiayaan Mudharabah Bermasalah di BMT Bina Ummat}

Salah satu aspek penting dalam perbankan syariah adalah proses pembiayaan yang sehat. Menurut Suhardjono, operasional pembiayaan meliputi pemasaran pembiayaan, prosedur pemberian pembiayaan, dokumentasi dan administrasi pembiayaan, pengawasan dan pembinaan pembiayaan, pengelolaan pembiayaan bermasalah dan penyelesaian pembiayaan bermasalah. (Suhardjono, 2003:161).

\section{a. Pembiayaan Mudharabah di BMT Bina Ummat Sejahtera cabang Mijen kudus}

Pembiayaan di BMT Bina Ummat Sejahtera ada bermacammacam, salah satunya adalah yang menggunakan akad mudharabah. Akad pembiayaan mudharabah adalah akad pembiayaan antara dua pihak, dimana BMT sebagai shohibul maal (penyedia modal) dan anggota sebagai mudhorib (pengelola usaha), atas kerjasama 
Analisis Implementasi Penanganan Pembiayaan Mudharabah Bermasalah...

ini berlaku sistem bagi hasil dengan ketentuan nisbah sesuai kesepakatan kedua belah pihak.

Akad pembiayaan mudharabah yang diterapkan di BMT Bina Ummat Sejahtera adalah akad mudharabah mutlaqah, yang mana pengertian dari mudharabah mutlaqah adalah bentuk kerja sama antara pihak shohibul maal dan mudhorib yang mana dalam kerja sama ini pihak BMT (shohibul maal) memberikan keleluasan penuh kepada pengelola (mudharib) dalam menentukan jenis usaha maupun pola pengelolaan yang dianggapnya baik dan menguntungkan sepanjang tidak bertentangan dengan ketentuan syariah.

Pembiayaan mudharabah di BMT BUS disalurkan kepada para pengusaha usaha mikro kecil menengah, para petani, pedagang, maupun peternak.Pembiayaan Mudharabah yang disalurkan oleh BMT BUS tidak terbatas jumlahnya, tergantung dari jaminan yang diajukan oleh mudhorib. Jika jaminan yang diajukan oleh mudhorib jumlahnya besar maka modal yang diberikan oleh BMT BUS juga besar. Namun jika jaminan yang diajukan oleh mudhorib jumlahnya kecil maka modal yang diberikan juga kecil.Jaminan yang diajukan oleh mudhorib kepada pihak BMT biasanya berupa BPKB kendaraan bermotor, sertifikat tanah dan sertifikat rumah.

Pembiayaan mudharabah yang ada di BMT BUS berdasarkan lama waktu pembiayaan yang diberikan ada yang 1 bulan, 3 bulan dan 6 bulan.Namun maksimal jangka waktu jatuh tempo pembiayaan adalah 6 bulan. BMT BUS juga menawarkan opsi untuk pengembalian modal pembiayaan yaitu : modal di kembalikan pada waktu jatuh tempo, ataupun di angsur setiap bulannya. Misalkan : modal yang diberikan oleh BMT BUS Rp 6.000.000,- . jangka waktu pembiayaan sampai 6 bulan, maka modal yang dikembalikan per-bulan adalah $\mathrm{Rp} 1.000 .000,-$. sehingga jika di total selama 6 bulan adalah Rp 1.000.000,- X 6 bulan $=\operatorname{Rp~6.000.000,-.angsuran~}$ modal tersebut belum termasuk pada bagi hasil karena bagi hasil pembiayaan Mudharabah di atur sesuai dengan kesepakatan antara shohibul maal dan mudharib.(Arianingsih, Wawancara Marketing, KSPPS BMT BUS cabang Mijen, Kudus, 16 Februari 2017) 


\section{b. Pemasaran Pembiayaan Mudharabah di KSPPS BMT Bina Ummat Sejahtera cabang Mijen Kudus}

Berdasarkan wawancara yang dilakukan peneliti kepada Bapak Kiki David.Dalam melakukan pemasaran baik pemasaran dalam hal funding maupun lending. Dalam pengelolaan pembiayaan, pihak BMT mempunyai tugas untuk membidik pasar yang mempunyai prospek yang bagus, mencari nasabah yang berpotensi, sekaligus mendampingi dan mengawal nasabah mulai dari proses pengajuan pembiayaan, pencairan, penagihan, dan pelunasan. Sedangkan dalam hal pemasaran produk, lembaga mengupayakan untuk membantu mempromosikan produkproduk mereka ke pihak-pihak tertentu lewat media pameran, baik yang diselenggarakan oleh pemerintah maupun swasta. Kualitas produk dari usaha anggota sering dikomunikasikan agar pasaran tidak ketinggalan dengan produk-produk lain.(Kiki David Panca Nugraha, Wawancara Korlap , KSPPS BMT BUS cabang Mijen, Kudus, 15 Februari 2017).

c. Prosedur Pemberian Pembiayaan Mudharabah di KSPPS BMT Bina Ummat Sejahtera cabang Mijen Kudus

1) Praktek Pemberian Pembiayaan

Dalam menjalankan praktek pembiayaan mudharabah, BMT Bina Ummat Sejahtera (BUS) menetapkan beberapa syarat dan ketentuan bagi para calon mudharib untuk memperoleh pembiayaan mudharabah, yaitu :

a. Mengisi formulir permohonan pembiayaan.

b. Foto copi kartu identitas KTP/SIM suami dan istri.

c. Foto copi KK atau Surat Nikah.

d. Foto copi Surat Jaminan (2 lembar)

e. Bersedia di Survey/ Silaturahmi.

f. Menjadi anggota KSPPS BMT Bina Ummat Sejahtera

2) Analisa Pembiayaan

Adapun pendekatan analisa yang digunakan KSPPS BMT Bina Ummat Sejahtera cabang Mijen Kudus dalam melakukan analisa pembiayaan yaitu pendekatan analisa 5 C. 
a. Character, KSPPS BMT Bina Ummat Sejahtera cabang Mijen Kudus akan melakukan analisa yang meliputi watak, sifat, dari calon nasabahnya.

b. Capacity, kemampuan calon nasabah KSPPS BMT Bina Ummat Sejahtera cabang Mijen Kudus dalam mengembalikan pinjaman pokok dan juga bagi hasil yang sudah menjadi kesepakatan di awal pinjaman.

c. Capital, modal yang dimiliki sendiri oleh calon nasabah diluar dari modal pembiayaan dari KSPPS BMT Bina Ummat Sejahtera cabang Mijen Kudus.

d. Collateral, nilai jaminan yang diajukan oleh calon nasabah KSPPS BMT Bina Ummat Sejahtera cabang Mijen Kudus sepadan atau tidak nilainya dengan nilai pembiayaan yang diberikan.

e. Condition, kondisi usaha nasabah. (Kiki David Panca Nugraha, Wawancara Korlap , KSPPS BMT BUS cabang Mijen, Kudus, 15 Februari 2017)

\section{d. Pengawasan dan Pembinaan Pembiayaan Mudharabah di KSPPS BMT Bina Ummat Sejahtera cabang Mijen Kudus}

Pengawasan kredit adalah kegiatan pengawasan/ monitoring terhadap tahapan-tahapan proses pemberian kredit, pejabat kredit yang melaksanakan proses pemberian kredit serta fasilitas kreditnya. Pengawasan kredit dapat dilakukan berdasarkan pada laporan yang disampaikan secara berkala dan atau informasi yang relevan (off site) maupun peninjauan secara langgsung (on site) atas seluruh kegiatan usaha debitur.Pengawasan secara langsung maupun tidak langsung dilakukan dalam rangka pembinaan kepada debitur untuk mendeteksi secara dini kemungkinan adanya masalah yang timbul dan berisiko bagi keamanan kredit yang telah diberikan. (Suhardjono, 2003: 230-232)

Pengawasan pembiayaan dapat diartikan sebagai salah satu fungsi manajemen KSPPS BMT Bina Ummat Sejahtera cabang Mijen Kudus yang berupaya untuk menjaga dan mengamankan pembiayaan. Dalam wawancara yang peneliti lakukan kepada Bapak Saiful Muhib, secara umum terdapat dua cara pengawasan pembiayaan, yaitu pengawasan secara administrative dan pengawasan secara fisik. 
1) Pengawasan administrative

Pengawasan administrative pembiayaan merupakan pengawasan data-data maupun surat kelengkapan pembiayaan nasabah terkait. Yang dilakukan pihak BMT adalah mengkaji dokumen.Marketing pembiayaan melakukan kajian terhadap dokumen pembiayaan yang telah masuk dari bagian pembiayaan. Kemudian marketing pembiayaan akan melakukan kaian terhadap dana pembiayaan, rencana pengembangan dana pembiayaan yang akan digunakan oleh anggota, dan seberapa jauh kebutuhan riil anggota.

2) Pengawasan secara langsung

KSPPS BMT Bina Ummat Sejahtera cabang Mijen Kudus melakukan pemerikasaan langsung ketempat usaha nasabah yang dibiayai. Dalam hal ini BMT melakukan analisa pembiyaan dan pemantauan kondisi usaha. Sebelum pengajuan pembiayaan disetujui dan dilakukan pencairan dana pembiayaan, maka pihak marketing pembiayaan dan korlap akan melakukan analisa pembiayaan yang memperhatikan prinsip 5C, penggunaan prinsip $5 \mathrm{C}$ dilakukan dengan melalui kunjungan atau survey kepada calon nasabah. Pemantauan kondisi usaha dan penggunaan pembiayaan. Setelah dana dicairkan pihak BMT BUS memantau pembiayaan yang telah terealisasi. Apakah anggota menggunakan dana pembiayaan seutuhnya untuk kegiatan produktif ataukah sebagian digunakan untuk keperluan konsumtif anggota? Apakah usaha yang dijalankan oleh anggota berjalan dengan lancar atau tidak?Bagaimana kondisi pembayaran angsuran pokok dan juga bagi hasil lancar atau mengalami keterlambatan setiap bulannya?

e. Pengelolaan Pembiayaan Mudharabah Bermasalah di KSPPS BMT Bina Ummat Sejahtera cabang Mijen Kudus

Hampir setiap bank mengalami pembiayaan bermasalah alias nasabah tidak mampu lagi untuk melunasi kreditnya. Kemacetan suatu fasilitas kredit disebabkan oleh 2 faktor yaitu: 
Analisis Implementasi Penanganan Pembiayaan Mudharabah Bermasalah...

1) Dari pihak perbankan

Dalam hal ini pihak analisis kredit kurang teliti baik dalam mengecek kebenaran dan keaslian dokumen maupun salah dalam melakukan perhitungan dengan rasio-rasio yang ada. Akibatnya apa yang seharusnya terjadi, tidak diprediksi sebelumnya. Kemacetan suatu kredit dapat pula terjadi akibat kolusi dari pihak analisis kredit dengan pihak debitur sehingga dalam analisisnya dilakukan secara tidak obyektif.

2) Dari pihak nasabah.

Kemacetan kredit yang disebabkan oleh nasabah diakibatkan 2 hal yaitu:

a. Adanya unsur kesengajaan. Artinya nasabah sengaja tidak mau membayar kewajibannya kepada bank sehingga kredit yang diberikan dengan sendiri macet.

b. Adanya unsur tidak sengaja. Artinya nasabah memiliki kemauan untuk membayar akan tetapi tidak mampu dikarenakan usaha dibiayai terkena musibah misalnya kebanjiran atau kebakaran.(Kasmir, 2002:115).

Berdasarkan wawancara dengan Ibu Arianingsih selaku marketing di KSPPS BMT BUS cabang Mijen Kudus mengatakan kualitas pembiayaan yang ada di BMT BUS tidak dapat dikatakan semua lancar, namun ada juga anggota yang dalam kategori pembiyaan bermasalah.

Pembiayaan mudharabah yang disalurkan oleh BMT BUS sejauh ini juga ada yang dapat dikategorikan dalam pembiayaan bermasalah. Adapun faktor-faktor yang menyebabkan pembiayaan bermasalah di BMT BUS itu berasal dari BMT itu sendiri dan dari anggota, antara lain:

1) Survey kurang maksimal. Seperti wawancara dengan Ibu Arianingsih selaku marketing.

"Biasanya anggota pembiayaan itu dalam memberikan penjelasan itu tidak benar, ceritanya diada-ada, katanya punya usaha ini ternyata kenyataannya tidak punya usaha tersebut".

Kesalahan BMT dalam memberikan fasilitas pembiayaan.(Arianingsih, Wawancara Marketing , KSPPS 
BMT BUS cabang Mijen, Kudus, 16 Februari 2017).Hal ini disampaikan pula oleh Bpk Harun selaku marketing.

"Kita sudah memberikan pembiayaan kepada anggota, yang pada akad awal untuk usaha dagang ternyata malah untuk beli motor, kan tidak sesuai dengan akad awal". (Lukman Harun, Wawancara Marketing Cabang, KSPPS BMT BUS cabang Mijen, Kudus, 16 Februari 2017).

2) Dari anggota, antara lain:

- Menyalahi penggunaan akad

- Karakter anggota tidak jujur dalam memberikan informasi yang dijalankan.

- Anggota suka mengulur-ngulur waktu pembayaran pembiayaan.

- Kondisi pasar yang tidak menentu, sering berubah-ubah harganya. Terjadi kenaikan dan penurunan harga pasar.

- Terjadi bencana alam.

Terjadi kematian. Jika terjadi kematian apabila anggota masih menanggung pembiayaan, tanpa adanya ahli waris yang menanggung pembiayaan tersebut, maka pembiayaan itu akan diasuransikan dengan catatan apabila tidak jatuh tempo, jika sudah jatuh tempo maka asuransi tersebut akan hangus.

Dalam menangani pembiayaan mudharabah bermasalah maka, perlu adanya upaya-upaya penanganan pembiayaan mudharabah bermasalah yang dilakukan oleh BMT BUS cabang Mijen Kudus. Adapun upaya-upaya tersebut, sesuai dengan hasil wawancara kepaada Bapak David, antara lain:

1) Dikelompokkan.

Sebelum dilakukan tindakan, maka pihak BMT akan mengelompokkan pembiayaan ke dalam kategori lancar, kurang lancar, diragukan dan juga macet.

2) Peringatan melalui telepon.

Setelah membuat daftar kolektabilitas yang termasuk kedalam kurang lancar, diragukan, dan macet akan diberitahukan melalui telepon. Dengan tujuan mengingatkan anggota bahwa sudah waktunya untuk membayar angsuran 
pembiayaanya.(Kiki David Panca Nugraha, Wawancara Korlap, KSPPS BMT BUS cabang Mijen, Kudus, 15 Februari 2017).

3) Silaturrahmi/Kunjungan anggota.

Anggota yang tergolong ke dalam kurang lancar, diragukan, dan macet akan mendapatkan jadwal kunjungan oleh pihak BMT. Pihak BMT akan melakukan kunjungan guna mengingatkan, menanyakan, dan mencari tahu kondisi sebenarnya yang telah dialami oleh anggota sehingga menyebabkan ketidakmampuan anggota membayar angsuran secara tepat waktu atau kurang lancar dalam membayar atau sama sekali tidak membayar angsuran baik pokok maupun bagi hasilnya. Namun ada kendala juga ketika pihak BMT akan melakukan kunjungan kerumah anggota. (Arianingsih, Wawancara Marketing, KSPPS BMT BUS cabang Mijen, Kudus, 15 Februari 2017).

Bapak Harun selaku marketing pembiayaan menyatakan:" Kunjungan yang dilakukan oleh pihak BMT tidak gampang, karena terkadang anggota sulit sekali ditemui dirumahnya".

4) Rapat/musyawarah kantor.

Setelah melakukan kunjungan dan pihak BMT yang melakukan kunjungan tersebut sudah menemukan masalah yang telah dialami oleh anggota, maka pihak BMT yang melakukan kunjungan tersebut lapor kekantor dan melakukan rapat akan hasil kunjungan tersebut untuk mendapatkan solusi. Permasalahan tersebut dimusyawarahkan bersama.

5) Pemberian surat peringatan I, II, III.

Setelah dilakukan musyawarah untuk pembiayaan yang tergolong macet, maka pihak BMT akan memberikan SP kepada anggota. SP I berisi pemberitahuan penagihan mengenai nominal tunggakan angsuran pokok dan bagi hasil. SP II berisi pemberitahuan penagihan dengan mendatangi rumah anggota.(Lukman Harun, Wawancara Manajer Cabang, KSPPS BMT BUS cabang Mijen, Kudus, 16 Februari 2017). 


\section{f. Penanganan Pembiayaan Mudharabah Bermasalah di KSPPS BMT Bina Ummat Sejahtera cabang Mijen Kudus}

Untuk menyelesaikan pembiayaan mudharabah bermasalah, KSPPS BMT Bina Ummat Sejahtera cabang Mijen Kudus mempunyai langkah penyelesaian dengan menerapkan cara-cara sebagai berikut:

Penyelamatan yaitu upaya yang dilakukan di dalam pengelolaan kredit bermasalah yang masih mempunyai prospek di dalam usahanya dengan tujuan untuk meminimalkan kemungkinan timbulnya kerugian bagi bank, menyelamatkan kembali kredit yang ada agar menjadi lancar, serta usaha -usaha lainnya yang ditujukan untuk memperbaiki kualitas usaha debitur.

Tindakan yang dapat digolongkan ke dalam upaya ini adalah: rescheduling, reconditioning, restructuring, bimbingan manajemen dan penyertaan bank. (Veithzal Rivai, 2013:455)

Dari hasil penelitian menunjukkan bahwa, penyelamatan pembiayaan bermasalah yang dilakukan oleh BMT BUS cabang Mijen Kudus dalam menangani pembiayaan mudharabah bermasalah, antara lain:

1) Penjadawalan Kembali (Rescheduling)

Penjadawalan kembali (rescheduling), yaitu perubahan syarat kredit yang hanya menyangkut jadwal pembayaran atau jangka waktunya yang meliputi: perubahan grace period, perubahan jadwal pembayaran, perubahan jangka waktu, dan perubahan jumlah angsuran. (Suhardjono,2007:272)

Dari hasil penelitian menunjukkan bahwa, penjadwalan kembali yang dilakukan oleh KSPPS BMT BUS cabang Mijen Kudus merupakan suatu proses untuk memberikan kelonggaran jangka waktu kepada anggota, setelah jangka waktu maksimal jatuh tempo yang telah ditentukan, anggota tidak dapat mengembalikan modal yang telah dipinjam dari BMT BUS cabang Mijen Kudus.

Upaya penjadwalan kembali dilakukan oleh BMT karena berdasarkan analisis pihak BMT BUS cabang Mijen Kudus melihat bahwa usaha anggota mempunyai prospek untuk bangkit dan anggota mempunyai niat dan kemauan 
untuk mengembalikan modal jika waktu pengembalian modal diperpanjang.

Upaya ini dilakukan oleh BMT karena melihat bahwa prospek keuangan anggota di masa depan menjanjikan, sehingga anggota diharapkan bisa mengembalikan modal dimasa depan. Selain itu pihak BMT juga melakukan pengawasan kepada anggota, agar anggota tidak lalai untuk mengembalikan modalnya.

Penjadwalan kembali biasanya diberikan kepada anggota dengan kelonggaran waktu 1 kali waktu maksimal jatuh tempo, yaitu 6 bulan lagi setelah waktu jatuh tempo maksimal 6 bulan yang telah ditentukan.

Namun untuk nasabah yang nakal atau sengaja mengulur waktu dalam mengembalikan modal pembiayaan mudharabah biasanya jangka waktu yang diberikan lebih sedikit, yaitu 3 bulan setelah waktu jatuh tempo pembiayaan mudharabah.

Perbedaan lama waktu pengembalian modal antara anggota yang nakal dan yang tidak merupakan cara yang cukup efektif dalam menyelesaikan pembiayaan mudharabah bermasalah dengan cara penjadwalan kembali, sebab untuk anggota yang nakal biasanya sengaja mengulur-ulur waktu dalam mengembalikan modal pembiayaan. Sedangkan untuk anggota yang murni tidak mampu untuk mengembalikan modal, maka jangka waktu yang diberikan lebih lama.Dalam pembiayaan mudharabah idealnya jika anggota (mudharib) belum mampu atau tidak mampu mengembalikan modal mudharabah berdasarkan lama waktu jatuh tempo, maka anggota (mudharib) sebenarnya tidak harus mengembalikan modal pembiayaan mudharabah karena kerugian dalam menjalankan usaha maka yang menaggung kerugian adalah shohibul maal.Namun untuk anggota yang nakal karena sengaja tidak mengembalikan modal mudharabah, maka anggota harus tetap mengembalikan modal mudharabah.

Upaya-upaya penyelamatan dengan cara penjadwalan kembali (rescheduling) waktu pengembalian dirasa cukup 
efektif karena dengan cara ini dapat memberikan kelonggaran kepada anggota dalam mengembalikan modalnya, sehingga anggota bisa menjaga amanah yang telah diberikan oleh BMT BUS cabang Mijen Kudus. Serta anggota bisa memanfaatkan kesempatan yang diberikan oleh BMT BUS cabang Mijen Kudus (sebagai shohibul maal).

Sebagaimana Firman Allah dalam QS Al-Baqarah ayat 280

Artinya:" Dan jika (orang yang berhutang itu) dalam kesukaran, maka berilah tangguh sampai dia berkelapangan. Dan menyedekahkan (sebagian atau semua utang) itu, lebih baik bagimu, jika kamu mengetahui".

Dalam ayat diatas dapat direfleksikan dalam pembiayaan mudharabah yang mana jika mudharib (anggota) tidak dapat mengembalikan modalnya pada saat berakhirnya akad, proses penjadwalan kembali merupakan tahapan yang mempermudah mudharib (anggota) dalam mengembalikan modal mudharabah yang telah dipinjam. Baik itu untuk anggota yang nakal atau tidak.

Pemberian penangguhan atau perpanjangan jangka waktu pelunasan pembiayaan yang telah diberikan oleh pihak BMT BUS cabang Mijen Kudus kepada anggota, harus dilakukan dengan akad yang baru dan tidak boleh menyambung dengan akad yang lama karena otomatis akad yang lama sudah rusak dan harus diganti dengan akad yang baru. Jadi akad yang baru dimulai dengan kesepakatan baru yaitu dengan kesepakatan baru berapa lama anggota akan melunasi sisa pembiayaan tersebut.

2) Pemberian Keringanan Angsuran

Pemberian keringanan angsuran dilakukan oleh BMT BUS dengan maksud agar mudharib bisa mengembalikan modal yang telah disalurkan oleh shohibul maal setelah waktu yang telah ditentukan tidak bisa mengembalikan

Pemberian keringanan angsuran dimaksudkan untuk memberikan kemudahan bagi anggota agar dapat 
mengembalikan modalnya setelah masa jatuh tempo yang ditentukan telah lewat.

Upaya pemberian keringanan angsuran dimaksudkan untuk meringankan beban anggota dalam mengembalikan modal pembiayaan mudharabah, karena angsuran yang telah ditetapkan terlalu berat untuk anggota, sehingga anggota tidak mampu mengembalikan modalnya sesuai yang telah ditentukan.

Dengan adanya pemberian keringanan angsuran kepada anggota, diharapkan anggota mempunyai komitmen untuk mengembalikan modalnya pada waktu yang telah ditentukan sesuai dengan kesepakatan yang baru. Mengenai keringanan angsuran yang diberikan oleh BMT BUS cabang Mijen Kudus kepada pihak anggota, besarnya sesuai dengan kesepakatan antara BMT BUS cabang Mijen Kudus dengan anggota. Hal ini dilakukan berdasarkan kesepakatan bersama agar anggota tidak merasa terbebani dengan angsuran modal yang telah ditetapkan oleh pihak BMT.Sehingga berdasarkan penjadwalan kembali waktu yang telah ditentukan dan keringanan angsuran yang telah ditetapkan oleh pihak BMT, diharapkan anggota bisa mengembalikan modal yang telah disalurkan oleh BMT.Pemberian keringanan angsuran untuk anggota antara yang nakal dengan yang tidak nakal dibedakan basaran nominalnya.

Misalkan : sisa pembiayaan mudharabah adalah $\mathrm{Rp}$ 600.000,- dan lama waktu yang ditentukan adalah 6 bulan, maka anggota setiap bulannya harus mengembalikan modal pembiyaan Rp 100.000,--

Sedangkan untuk nasabah yang nakal angsuran pengembalian modal yang ditetapkan lebih besar, karena berdasarkan lama waktu penjadwalan kembali juga lebih singkat.

Misalkan : sisa pembiayaan mudharabah adalah $\mathrm{Rp}$ 600.000,- dan lama waktu yang ditentukan oleh BMT adalah 3 bulan, maka anggota harusmengembalikan Rp 200.000,setiap bulannya. 
Upaya pemberian keringanan angsuran merupakan upaya adanya iktikad baik dari kedua belah pihak dalam menjaga sikap untuk saling percaya.Cara ini cukup efektif dalam menangani pembiayaan mudharabah bermasalah di BMT BUS cabang Mijen Kudus.

3) Upaya dengan eksekusi jaminan ini dilakukan oleh BMT Bina Ummat Sejahtera cabang Mijen Kudus dengan maksud agar modal yang telah disalurkan bisa kembali dan bisa memberikan efek jera kepada anggota agar hal serupa tidak terulang lagi dikemudian hari. Namun jika anggota bangkrut dan usahanya mengalami kerugian atas kesalahannya sendiri setelah diberikannya dua opsi diatas maka pihak BMT BUS cabang Mijen Kudus harus tetap memberikan kesempatan kepada anggota lagi agar bisa mengembalikan kembali modal yang telah dipinjam oleh anggota dalam kurun waktu tertentu. Pelaksanaan eksekusi jaminan ini seharusnya hanya diperkenankan untuk anggota yang sengaja mengulu-ulur waktu pengembalian modal pembiayaan setelah diberikan kesempatan melalui opsi penjadwalan kembali dan pemberian keringanan angsuran, tetapi anggota tetap tidak mempunyai niatan untuk mengembalikan modalnya. Sehingga BMT BUS cabang Mijen Kudus idealnya melakukan hak ambil alih jaminan yang dijadikan agunan oleh anggota yang nakal, agar anggota tersebut menjadi jera.

Tabel. 4.1 Laporan Jumlah Pembiayaan Mudharabah yang Terealisasi dan Jumlah Pembiayaan Bermasalah di KJKS BMT Bina Umat Sejahtera Cabang Mijen Kudus dari Tahun 2013-2016.

\begin{tabular}{ccccc}
\hline Tahun & $\begin{array}{c}\text { Pembiayaan } \\
\text { Mudharabah }\end{array}$ & Rupiah & $\begin{array}{c}\text { Pembiayaan } \\
\text { Bermasalah }\end{array}$ & Rupiah \\
\hline 2013 & 205 & 1.053 .748 .576 & 52 & 194.252 .782 \\
2014 & 237 & 1.636 .283 .759 & 46 & 675.383 .900 \\
2015 & 297 & 1.936 .853 .301 & 25 & 604.855 .782 \\
2016 & 318 & 2.390 .703 .300 & 16 & 515.051 .821 \\
\hline
\end{tabular}

Sumber: Bagian Pembiayaan KJKS BMT Bina Umat Sejahtera Cabang Mijen Kudus

Artinya dari uraian tabel dia atas bahwa sistem penanganan pembiayaan bermasalah pada pembiayaan mudharabah bermasalah 
yang dilakukan oleh KSPPS BMT Bina Ummat Sejahtera Cabang Mijen Kudus sangat efektif dalam meminimalisir pembiayaan bermasalah bagi nasabah KSPPS BMT Bina Umat Sejahtera Cabang Mijen Kudus, terbukti dari data tabel di atas pembiayaan bermasalah semakin minim dan kecil.

\section{Simpulan}

Pembiayaan berdasarkan prinsip syariah oleh BMT mengandung risiko kegagalan atau kemacetan pelunasannya, sehingga dapat berpengaruh terhadap kesehatan BMT, termasuk KSPPS BMT Bina Ummat Sejahtera Cabang Mijen Kudus. Sistem penanganan pembiayaan bermasalah pada pembiayaan mudharabah yang dilakukan oleh KSPPS BMT Bina Ummat Sejahtera Cabang Mijen Kudus sangat efektif untuk meminimalisir pembiayaan bermasalah bagi anggota KSPPS BMT Bina Umat Sejahtera Cabang Mijen Kudus.

Penanganan pembiayaan mudharabah bermasalah yang dilakukan oleh KSPPS BMT Bina Ummat Sejahtera cabang Mijen Kudus meliputi pembiayaan mudharabah, pemasaran pembiayaan mudharabah, prosedur pemberian pembiayaan mudharabah, pengawasan dan pembinaan pembiayaan mudharabah, pengelolaan pembiayaan mudharabah bermasalah dan penyelesaian pembiayaan mudharabah bermasalah sudah sesuai dan berdampak positif. 


\section{DAFTAR PUSTAKA}

Abu Qasim Ahmad Thabrani. 1451H. al Mu'jam al Ausath, Dar al Haramain. Kairo. Maktabah Syamilah.

Assobar Qur'an Mushaf Al-Majid Kementerian Agama RI. AlQur'an dan Terjemahan Untuk Keluarga. Pustaka Al-Mubin, Jakarta Timur.

Didiek Ahmad Supadie. 2013. Sistem Lembaga Keuangan Ekonomi Syariah Dalam Pemberdayaan Ekonomi Rakyat. Pustaka Rizki Putra, Semarang.

Ismail. 2011. Perbankan Syariah. Prenadamedia Group: Jakarta.

Kasmi. 2002. Bank dan Lembaga Keuangan Lainnya. PT Raja Grafindo Persada: Jakarta.

Kasmir. 2002. Manajemen Perbankan. RajaGrafindo Persada: Jakarta.

Makhalul Ilmi. 2002. Teori dan Praktek Lembaga Mikro Keuangan Syariah. UII Press: Yogyakarta.

Muhammad Ridwan. 2005. Manajemen Baitul Maal Wa Tamwil. UII Press: Yogyakarta.

Muhammad Syafi'i Antonio. 2001. Bank Syariah Dari Teori Ke Praktik. Gema Insani: Jakarta.

Sayyid Sabiq. FiqhusSunnah. Al Fath I'lam al Arabi. Kairo, tt.

Suhardjono. Manajemen Perkreditan Usaha Kecil dan Menengah. (UPP) AMP YKPN. Yogyakarta. hlm. 272.

Suhardjono. 2003. Manajemen Perkreditan Usaha Kecil dan Menengah. UPP AMP YKPN: Yogyakarta.

Veithzal Rivai. 2013. Credit Management Handbook Manajemen Perkreditan Cara Mudah Menganalisis Kredit: Teori, Konsep, Prosedur, dan Aplikasi serta Panduan Praktis Bankir. Rajawali Pers: Jakarta.

Veithzal Rivai. 2008. Islamic Financial Management: Teori, Konsep Dan Aplikasi : Panduan Praktis Untuk Lembaga Keuangan, Nasabah, Praktisi, Dan Mahasiswa. Raja Grafindo Persada: Jakarta. 
Analisis Implementasi Penanganan Pembiayaan Mudharabah Bermasalah...

Wahbah Zuhaily. al-Figh al-Islami wa Adillatuhu, Dar al Fikr, Suriah, Damaskus. tt. Maktabah Syamilah.

\section{Wawancara}

Kiki David Panca Nugraha. Wawancara Korlap. KSPPS BMT BUS cabang Mijen, Kudus, 15 Februari 2017.

Lukman Harun. Wawancara Marketing Cabang. KSPPS BMT BUS cabang Mijen, Kudus, 16 Februari 2017.

Arianingsih. Wawancara Marketing. KSPPS BMT BUS cabang Mijen, Kudus, 16 Februari 2017.

Lukman Harun. Wawancara Manajer Cabang, KSPPS BMT BUS cabang Mijen, Kudus, 16 Februari 2017. 
Fuad Riyadi \& Sri Puji Lestari 